\title{
ASPEK HUKUM PENGCOVERAN LAGU DITINJAU DARI UNDANG-UNDANG HAK CIPTA
}

\author{
Iwan Sandi Panagarso, S.H., ${ }^{1}$ M.H. Calvindo Bagas $S^{2}$ \\ Fakultas Hukum Universitas Muhammadiyah Gresik
}

\begin{abstract}
ABSTARCT
Factors affecting the violation of copyright in songs or music in Indonesia are economic factors, socio-cultural factors, educational factors, weak law enforcement against violators. The forms of copyright infringement in Indonesia, namely Bootleg, namely piracy committed when the singer performs (Live Show). Counterfeit is a song hijacking done by copying directly, copying the cover and packaging exactly and Pirate is done by using various songs and various record albums that sell in the market.
\end{abstract}

Keywords: Song Provision Law, Aspect Viewed From, Copyright Law.

\section{PENDAHULUAN}

Dalam industri musik, dari sudut perlindungan hak cipta dibedakan antara komposisi musik/lagu (music composition) dan rekaman suara (sound recordings). Komposisi musik terdiri dari musik, termasuk di dalamnya syair/lirik. Komposisi musik dapat berupa sebuah salinan notasi atau sebuah rekaman awal (phonorecord) pada kaset rekaman atau CD. Komposer/pencipta lagu dianggap sebagai pencipta dari sebuah komposisi musik.

Sementara itu, rekaman suara (sound recording) merupakan hasil penyempurnaan dari serangkaian suara-suara baik yang berasal dari musik, suara manusia dan atau suara-suara lainnya. Dianggap sebagai pencipta dari sound recording adalah pelaku/performer (dalam hal pertunjukan) dan atau produser rekaman (record producer) yang telah memproses suara-suara dan menyempurnakannya menjadi sebuah rekaman final.

Hak cipta pada sebuah rekaman suara tidak dapat disamakan dengan, atau tidak dapat menggantikan hak cipta pada komposisi musiknya yang menjadi dasar rekaman suara tersebut. Dalam Undang-Undang No.19 Tahun 2002 tentang Hak Cipta (“UU Hak Cipta”),

\footnotetext{
${ }^{1}$ Dosen pada Prodi Hukum Fakultas Hukum Universitas Muhammadiyah Gresik

${ }^{2}$ Mahasiswa Fakultas Hukum Universitas Muhammadiyah Gresik
} 
perlindungan hak cipta atas komposisi musik disebut pada Pasal 12 ayat (1) huruf d UU Hak Cipta, sementara perlindungan hak cipta atas rekaman suara disebut pada Pasal 49 ayat (1) dan (2) UU Hak Cipta.

Cover version atau cover merupakan hasil reproduksi atau membawakan ulang sebuah lagu yang sebelumnya pernah direkam dan dibawakan penyanyi/artis lain. Tidak sedikit, sebuah lagu cover version bahkan menjadi lebih terkenal daripada lagu yang dibawakan oleh penyanyi aslinya. Karenanya, banyak artis baru mencoba peruntungannya dengan membawakan lagu cover version dengan tujuan agar lebih cepat sukses dan terkenal.

Untuk lagu-lagu cover yang diciptakan untuk tujuan komersial tadi, pencantuman Nama penyanyi asli saja pada karya cover tentu tidak cukup untuk menghindari tuntutan hukum pemegang hak cipta. Agar tidak melanggar hak cipta orang lain, untuk mereproduksi, merekam, mendistribusikan dan atau mengumumkan sebuah lagu milik orang lain, terutama untuk tujuan komersial, seseorang perlu memperoleh izin (lisensi) dari pencipta/pemegang hak cipta sebagai berikut:

1. Lisensi atas Hak Mekanikal (mechanical rights), yakni hak untuk menggandakan, mereproduksi (termasuk mengaransemen ulang) dan merekam sebuah komposisi musik/lagu pada $\mathrm{CD}$, kaset rekaman dan media rekam lainnya; dan atau

2. Hak Mengumumkan (performing rights), yakni hak untuk mengumumkan sebuah lagu/komposisi musik, termasuk menyanyikan, memainkan, baik berupa rekaman atau dipertunjukkan secara live (langsung), melalui radio dan televisi, termasuk melalui media lain seperti internet, konser live dan layanan-layanan musik terprogram.

\section{RUMUSAN MASALAH}

Adapun rumusan masalah dalam penelitian ini adalah factor yang mempengaruhi pelanggaran terhadap hak cipta dan bentuk pelanggaran terhadap hak cipta?

\section{ANALISA DAN PEMBAHASAN}

\section{Faktor-Faktor yang Mempengaruhi Pelanggaran Hak Cipta Lagu di Indonesia}

Di mata internasional Indonesia telah mendapat predikat sebagai bangsa pembajak karya cipta milik orang lain artinya tanpa memperdulikan hak-hak orang lain dengan membuat produk bajakan dalam bentuk cakram optik seperti CD, VCD, DVD, MP3, MP4 dan lain sebagainya yang mampu mencetak dalam jumlah banyak, cepat dan dengan biaya murah dengan kwalitas yang hampir Sama dengan produk aslinya. 
Eddy Damian menyatakan bahwa di dalam CD, VCD atau DVD yang digandakan rekaman suaranya secara massal terkandung didalamnya sekumpulan hak cipta yang dapat dirinci sebagai berikut:

1. Hak Cipta pada setiap lagu dan teks yang ada didalamnya;

2. Hak Cipta pada setiap lirik-lirik lagu;

3. Hak Cipta pada musiknya; dan

4. Hak Cipta pada gambar atau fotografi yang terdapat pada sampul CD.

Priyono menyatakan salah satu karya teknologi elektronik adalah dengan diciptakannya kepingan yang dikenal dengan Nama CD, VCD dan DVD yang banyak digunakan untuk keperluan hiburan dan pendidikan. Untung Minardi mengungkapkan penciptaan lagu atau musik sebagai hasil karya cipta seni tidak hanya memiliki arti sebagai karya yang hadir yang dapat dilihat secara fisik namun juga sebagai sarana pemenuhan kebutuhan batiniah manusia. Oleh sebab itu sudah sewajarnya diperlukan perlindungan hukum terhadap karya cipta lagu tersebut. Berikut ini adalah faktor-faktor yang mempengaruhi terjadinya pelanggaran terhadap hak cipta di Indonesia, antara lain:

1. Faktor ekonomi

Faktor ekonomi merupakan faktor pendorong utama terjadinya pelanggaran hak cipta seperti pembajakan kaset. Tingkat pendapatan yang rendah dan tingkat pengangguran yang tinggi membuat masyarakat berupaya untuk menambah pendapatannya, yaitu melakukan pekerjaan apa saja walaupun hal tersebut melanggar norma-norma hukum. 


\section{Faktor sosial budaya}

Secara sosial dan budaya, masyarakat Indonesia belum terbiasa untuk membeli produk-produk asli, terutama produk dari industri rekaman. Ini juga didukung dengan kebudayaan masyarakat Indonesia yang dalam membeli sebuah produk hanya mengorientasikan pada harga barang tanpa melihat kualitas dari barang tersebut. Di bidang sosial budaya ini, dampak yang timbul dari semakin meluasnya pembajakan tersebut begitu beragam.

\section{Faktor pendidikan}

Selama ini masyarakat kurang mendapatkan sosialisasi terhadap adanya UndangUndang Hak Cipta. Dampak atas ketidaktahuan masyarakat akan undang-undang tersebut masyarakat tidak bisa membedakan antara kaset asli dan palsu.

\section{Lemahnya penegakan hukum terhadap pelaku pelanggaran}

Sebagai salah satu penyebab maraknya pelanggaran hak cipta seperti pembajakan kaset adalah kurang tegasnya aparat hukum dalam menangani pelanggaran yang terjadi. Rendahnya hukuman yang diberikan kepada pelanggar hak cipta menandakan penegakan hukum terhadap pelaku pelanggaran juga merupakan faktor utama lemahnya penegakan hukum di bidang hak cipta. Akibatnya, keadaan ini dijadikan alasan untuk menghalalkan kegiatan baik berupa pembajakan maupun pemasaran dari kaset tersebut.

\section{Bentuk-Bentuk Pelanggaran Terhadap Hak Cipta Lagu di Indonesia}

Pembajakan dapat dibagi ke dalam tiga kategori. Pertama, pembajakan sederhana, di mana suatu rekaman asli dibuat duplikatnya untuk diperdagangkan tanpa seizin produser atau pemegang hak yang sah. Kedua, rekaman yang dibuat duplikatnya, kemudian dikemas sedapat mungkin mirip dengan aslinya, tanpa izin dari pemegang hak ciptanya. Logo dan merek ditiru untuk mengelabui masyarakat. Ketiga, penggandaan perekaman pertunjukkan artis-artis tertentu tanpa ijin dari artis tersebut atau dari komposer atau tanpa persetujuan dari produser rekaman yang mengikat artis bersangkutan dalam suatu perjanjian kontrak. Ketiga bentuk reproduksi atau penggandaan tersebut di atas pada umumnya ditemukan dalam bentuk-bentuk kaset atau compact, walaupun adakalanya ditemukan dalam bentuk disc. 
Pembajakan hak cipta merupakan suatu pelanggaran. Pasal 113 Undang-Undang Nomor 28 Tahun 2014 mengatur bahwa:

1) Setiap Orang yang dengan tanpa hak melakukan pelanggaran hak ekonomi sebagaimana dimaksud dalam Pasal 9 ayat (1) huruf i untuk Penggunaan Secara Komersial dipidana dengan pidana penjara paling lama 1 (satu) tahun dan/atau pidana denda paling banyak Rp100.000.000 (seratus juta rupiah).

2) Setiap Orang yang dengan tanpa hak dan/atau tanpa izin Pencipta atau pemegang Hak Cipta melakukan pelanggaran hak ekonomi Pencipta sebagaimana dimaksud dalam Pasal 9 ayat (1) huruf c, huruf d, huruf f, dan/atau huruf h untuk Penggunaan Secara Komersial dipidana dengan pidana penjara paling lama 3 (tiga) tahun dan/atau pidana denda paling banyak Rp500.000.000,00 (lima ratus juta rupiah).

3) Setiap Orang yang dengan tanpa hak dan/atau tanpa izin Pencipta atau pemegang Hak Cipta melakukan pelanggaran hak ekonomi Pencipta sebagaimana dimaksud dalam Pasal 9 ayat (1) huruf a, huruf b, huruf e, dan/atau huruf g untuk Penggunaan Secara Komersial dipidana dengan pidana penjara paling lama 4 (empat) tahun dan/atau pidana denda paling banyak Rp1.000.000.000,00 (satu miliar rupiah).

4) Setiap Orang yang memenuhi unsur sebagaimana dimaksud pada ayat (3) yang dilakukan dalam bentuk pembajakan, dipidana dengan pidana penjara paling lama 10 (sepuluh) tahun dan/atau pidana denda paling banyak Rp4.000.000.000,00 (empat miliar rupiah).

Berdasarkan rumusan Pasal 113 di atas maka unsur-unsur pelanggaran, adalah sebagai berikut:

1. "setiap orang",

2. "dengan tanpa hak",

3. "tanpa izin Pencipta atau Pemegang Hak Cipta",

4. "pelanggaran hak ekonomi”,

5. "penggunaan secara komersial".

Di Amerika Serikat dan dalam industri musik internasional, perbanyakan suatu ciptaan baik secara keseluruhan maupun pada bagian-bagian tertentu, dengan menggunakan bahan-bahan yang sama atau tidak sama tersebut dapat dibagi dalam tiga (3) kategori: 


\section{Counterfeit}

Counterfeit merupakan bentuk pembajakan dengan melakukan penggandaan ulang suatu album karya rekaman, dalam bentuk sama sekali mirip dengan aslinya baik dalam kemasan album, ilustrasi cover maupun susunan lagunya.

\section{Piracy}

Piracy merupakan bentuk pembajakan karya rekaman yang dilakukan dengan menggunakan berbagai lagu dari yang sedang populer, dikenal dengan istilah "seleksi" atau ketikan. Piracy juga merupakan duplikasi yang ilegal terhadap produk yang telah direkam terlebih dahulu.

\section{Boot Legging}

Boot legging merupakan bentuk pembajakan yang dilakukan dengan cara merekam langsung suatu pertunjukkan musik dari seorang penyanyi, dan album rekaman ini digandakan lalu dijual sebagai album khusus dari penyanyi tersebut.

Pelanggaran dapat berupa perbuatan mengambil, mengutip, merekam, memperbanyak dan mengumumkan ciptaan orang lain, sebagian atau keseluruhan tanpa izin ini bertentangan dengan undang-undang hak cipta. Seperti yang kita ketahui bahwa hak cipta dibagi dalam dua kelompok besar, yaitu hak ekonomi dan hak moral. Perbuatan-perbuatan yang termasuk pelanggaran hak moral pencipta lagu adalah apabila tanpa izin berdasarkan Undang-Undang Hak Cipta Nomor 28 Tahun 2014:

1. meniadakan atau tidak menyebutkan nama pencipta lagu ketika lagu dipublikasikan;

2. mencantumkan namanya sebagai pencipta lagu padahal dia bukan pencipta lagu tersebut;

3. mengganti atau mengubah judul lagu; dan/atau;

4. mengubah isi lagu.

Dalam Penjelasan Umum Undang-Undang Hak Cipta Nomor 28 Tahun 2014 dinyatakan bahwa:

"perlindungan hak cipta tidak diberikan kepada ide atau gagasan karena karya cipta harus memiliki bentuk yang khas, bersifat pribadi, dan menunjukkan keaslian sebagai Ciptaan yang lahir berdasarkan kemampuan, kreativitas, atau keahlian sehingga Ciptaan itu dapat dilihat, dibaca, dan didengar." Menurut Harsono Adisumarto yang mengutip pendapat Soeharto mengungkapkan bahwa lagu atau musik terdiri dari unsur-unsur melodi, lirik dan aransemen.

Muhammad Ahkam menyatakan dalam menentukan"nilai" dari suatu karya cipta maka faktor nilai ekonomis yang perlu diperhatikan. Usia Hak Cipta untuk sebuah karya 
lagu adalah 50 tahun, sedangkan usia ekonomisnya tergantung dari kualitas dari lagu tersebut.

Untuk itulah diperlukan perlindungan hukum bagi setiap hasil ciptaan, agar penikmatan hasil karya tersebut dapat pula memberikan kesejahteraan bagi penciptanya. Husain Audah mengungkapkan di dalam Hak Cipta karya musik dan lagu biasanya terjadi pemisahan antara:

1. Pemilik Hak Cipta (pencipta), yaitu seorang pencipta lagu memiliki hak sepenuhnya untuk melakukan eksploitasi atas lagu ciptaannya yang berarti pihak-pihak yang ingin memanfaatkan karya tersebut harus meminta izin terlebih dahulu kepada penciptanya sebagai pemilik dan pemegang Hak Cipta;

2. Pemegang Hak Cipta (publisher), yaitu melekat pada penciptanya atau diserahkan kepada penerbit musik. Penerbit musik (music publishing) yang mendapat pengalihan hak sebagai pemegang Hak Cipta mempunyai fungsi memaksimalkan karya musik tersebut dan memasarkannya;

3. Pengguna Hak Cipta (users), yaitu untuk hak memperbanyak user adalah pengusaha rekaman, hak mengumumkan user adalah badan yang menggunakan karya musik atau lagu untuk keperluan komersial (hotel, restoran, karaoke dll), untuk printing rights user adalah badan yang menerbitkan karya musik dalam bentuk cetakan, baik melodi lagu maupun liriknya untuk keperluan komersial.

Husain menyatakan ada beberapa tindakan yang menyangkut pelanggaran di bidang hak cipta dan tindakan ilegal lainnya yaitu:

1. Pembajakan produksi rekaman musik, yaitu jenis pelanggaran ini adalah bentuk tindakan penggandaan, pengumuman dan pengedaran untuk kepentingan komersial yang dilakukan secara tidak sah, atau bentuk tindakan pemalsuan terhadap produksi yang legal;

2. Peredaran ilegal adalah sebuah produksi rekaman musik yang telah memenuhi semua kewajiban dan ketentuan terhadap materi produksi yang berkaitan dengan hak cipta, tapi peredarannya dilakukan secara ilegal. Artinya di dalam produksi tersebut tidak terdapat pelanggaran hak cipta, namun peredarannya melanggar peraturan perpajakan karena mengabaikan kewajiban pembayaran pajak PPn yang mengakibatkan kerugian bagi negara; 
3. Pelanggaran hak cipta, yaitu pelanggaran-pelanggaran terhadap hak cipta baik hak ekonomi maupun hak moral yang meliputi hal-hal seperti di bawah ini:

a. Peng-eksploitasi-an (pengumuman, penggandaan dan pengedaran) untuk kepentingan komersial sebuah karya cipta tanpa terlebih dahulu meminta izin atau mendapatkan lisensi dari penciptanya. Termasuk di dalamnya tindakan penjiplakan;

b. Peniadaan nama pencipta pada ciptaannya;

c. Penggantian atau perubahan nama pencipta pada ciptaannya dilakukan tanpa persetujuan dari pemilik hak ciptanya;

d. Penggantian atau perubahan judul sebuah ciptaan tanpa persetujuan dari penciptanya.

Syafrinaldi mengungkapkan kasus-kasus pelanggaran HKI di Indonesia seperti pembajakan berbagai karya-karya cipta semakin hari semakin tinggi secara kuantitas maupun kualitas. Anehnya, sangat jarang kasus-kasus pelanggaran tersebut yang sampai dinaikkan ke Pengadilan. Padahal, kasus-kasus pelanggaran HKI itu dapat ditemui dengan mudah di hampir setiap sudut Kota di Indonesia.

Endang Purwaningsih mengungkapkan segala bentuk perbanyakan dengan menggunakan media apapun merupakan suatu pelanggaran dan kepada pihak-pihak yang melanggar, harus diberikan sanksi agar pelanggaran ini tidak dapat terulang kembali.

Menurut Hendra Tanu Atmadja seperti dikutip oleh Rikson Sitorus mengungkapkan bahwa pembayaran terhadap pengalihan hak ekonomi pencipta biasanya dilakukan dengan dua cara yaitu sistem royalti dan sistem flat pay. Selama ini pencipta lagu mendapatkan honor yang dinilai secara flat pay, tanpa memperhitungkan jumlah unit kaset, CD,VCD dan DVD yang dijual yang diiringi dengan bonus, jika lagunya terpilih diurutan pertama sampul kaset dan mendapat honor tambahan, jika dijadikan seleksi, kompilasi dan lain-lain. Sistem royalti ini jika dibandingkan dengan cara flat berbeda dalam hal besarnya uang yang diterima di muka. Dengan cara flat, uang muka yang diterima lebih besar dibandingkan sistem royalti. Sebaliknya, sistem royalti memberikan kemungkinan pencipta mendapat imbalan yang lebih besar dikemudian hari, jika kaset tersebut laku dijual. 


\section{KESIMPULAN}

Berdasarkan uraian-uraian yang telah dikemukakan sebelumnya dalam kaitannya dengan pokok permasalahan yang ada, maka dapat diambil beberapa kesimpulan sebagai berikut :

1. Faktor yang mempengaruhi pelanggaran hak cipta lagu atau musik di Indonesia adalah faktor ekonomi, faktor sosial budaya, faktor pendidikan, lemahnya penegakan hukum terhadap pelaku pelanggaran.

2. Bentuk-bentuk pelanggaran hak cipta di Indonesia yakni Bootleg yakni pembajakan yang dilakukan saat penyanyi tampil (Live Show). Counterfeit yakni pembajakan lagu yang dilakukan dengan menggandakan langsung, meniru persis cover dan kemasannya dan Pirate yakni dilakukan dengan menggunakan berbagai lagu dan bermacam-macam album rekaman yang laku di pasaran.

\section{DAFTAR PUSTAKA}

Adisumarto, Harsono, Hak Milik Intelektual Khususnya Paten Dan Merek, Hak Milik Perindustrian (Industrial Property), jakarta: akademika pressindo, 1985.

Adrian, Sutedi, Hak Atas Kekayaan Intelektual, Jakarta, PT Sinar Grafika, 2009.

Ahmad, M. Ramli, Perlindungan Rahasia Dagang dalam Undang-Undang Nomor 30/2000 dan Perbandingannya Dengan Beberapa Negara, Bandung, CV. Mandar Maju, 2001.

Amirin, M. Tatang, Pokok-Pokok Teori Sistem, Jakarta: CV Rajawali, 1986.

Andriana, Krisnawati, dan Gazalba Saleh, Perlindungan Hukum Varietas Baru Tanaman, Jakarta, PT. Raja Grafindo Persada, 2004.

Arief, Sritua, dan Adi Sasono, Indonesia Ketergantungan Dan Keterbelakangan, Jakarta: Mizan, 2013.

Baxter, J.W, World Paten Law and Practice, London: Third Commulative Supplement, 1972.

Black, Donald, Sociological Justice, New York: Oxford University Press, 1989.

Budi, Agus Riswandi, dan M. Syamsudin, Hak Kekayaan Intelektual dan Budaya Hukum, Jakarta: Cetakan ke-1, Penerbit PT. Raja Grafindo Persada, 2004.

Damardjati S.D dan W.H. Adil, Development of Plant Variety Protection in Indonesia, Jakarta: Ministry of Agriculture, 2000.

Damian, Eddy, Hukum Hak Cipta, Bandung: Alumni, 2002.

Ditjen HKI dan ECAP II, Buku Panduan Hak Kekayaan Intelektual di Lengkapi Dengan Peraturan Perundang-Undangan di Bidang Hak Kekayaan Intelektual, Jakarta: Ditjen HKI dan ECAP II, 2006. 